\title{
STUDI FITOKIMIA EKSTRAK DAUN KEMANGI DAN DAUN KUMIS KUCING MENGGUNAKAN PELARUT METANOL
}

\author{
Surahmaida ${ }^{1 *}$, Umarudin ${ }^{1}$ \\ ${ }^{1}$ DIII Farmasi, Akademi Farmasi Surabaya, Ketintang Madya No. 81 Surabaya, 60231, Indonesia \\ * Author Utama, email: fahida1619@gmail.com \\ Co-author, email: umayudin47@yahoo.com
}

\begin{abstract}
Lamiaceae is an aromatic plant that is commonly used as a medicinal plant. The purpose of this study is to analyze phytochemical compounds of the Lamiaceae tribe, namely leaves of kemangi (Ocimum sanctum) and leaves of kumis kucing (Orthosiphon stamineus). This research method consisted of extraction using maceration method using methanol solvent for 3 days (and repeated twice), then phytochemical tests using chemical reagents were carried out to determine the presence of alkaloids, flavonoids, tannins, saponins, steroids, terpenoids and essential oils contained in both extracts of the test plant. The phytochemical test results showed methanol extract of kemangi leaves containing alkaloids, flavonoids, tannins, saponins, terpenoids, steroids and essential oils; while the methanol extract of kumis kucing leaves contains flavonoids, saponins, tannins and essential oils. The secondary metabolites are then theoretically studied for their biological activities.
\end{abstract}

Keywords: Ocimum sanctum leaves; Orthosiphon stamineus leaves; phytochemical screening

\section{ABSTRAK}

Tanaman suku Lamiaceae merupakan tanaman aromatik yang umumnya digunakan sebagai tanaman obat. Tujuan dari penelitian ini untuk menganalisis senyawa fitokimia dari tanaman suku Lamiaceae yaitu daun kemangi (Ocimum sanctum) dan kumis kucing (Orthosiphon stamineus). Metode penelitian ini terdiri dari ekstraksi dengan metode maserasi menggunakan pelarut metanol selama 3 hari (dan diulang dua kali), lalu dilakukan uji fitokimia menggunakan reagen kimia untuk mengetahui adanya senyawa alkaloid, flavonoid, tannin, saponin, steroid, terpenoid dan minyak atisiri yang terkandung pada kedua ekstrak tanaman uji tersebut. Hasil uji fitokimia menunjukkan ekstrak metanol daun kemangi mengandung alkaloid, flavonoid, tannin, saponin, terpenoid, steroid dan minyak atsiri; sedangkan ekstrak metanol daun kumis mengandung flavonoid, saponin, tannin dan minyak atsiri. Senyawa-senyawa metabolit sekunder tersebut kemudian dikaji secara teoritis aktivitas biologisnya.

Kata Kunci: daun kemangi; daun kumis kucing; senyawa fitokimia

\section{PENDAHULUAN}

Tanaman suku Lamiaceae termasuk tanaman aromatik yang terdiri dari 46 genus dan 410 spesies tanaman yang tersebar di seluruh dunia [1]. Umumnya tanaman Lamiaceae banyak digunakan oleh masyarakat dunia sebagai tanaman obat tradisional untuk mengobati berbagai penyakit [2], rempah-rempah dan tanaman pangan [3], bumbu penyedap serta wewangian [4].
Saat ini, banyak penelitian yang melakukan studi fitokimia dari tanaman obat. Fitokimia (disebut juga metabolit sekunder) merupakan senyawa kimia yang terdapat pada tanaman dan memiliki berbagai macam aktivitas biologis, seperti antimikroba, antifungi, antioksidan dan lain-lain. Senyawasenyawa fitokimia ini meliputi alkaloid, flavonoid, tannin, saponin dan senyawa fenol lainnya [5]. Pengujian fitokimia pada 
tanaman suku Lamiaceae telah dilakukan oleh [6] yaitu pada Ocimum sanctum, Leonotis nepetifolia, Mentha arvensis. Tanaman Lamiaceae lainnya yaitu Leucas linifolia, Coleus aromaticus dan Pogestemon patchouli [7], Orthosiphon stamineus, Ocimum basilicum [8]. Uji fitokimia pada tanaman obat terus dikembangkan untuk mengembangkan bahan obat baru atau menemukan senyawa penting lainnya yang dapat diaplikasikan dalam ilmu lain [9].

Dari berbagai macam tanaman Lamiaceae yang telah diteliti, namun masih belum ada penelitian tentang pengujian fitokimia daun kemangi (Ocimum sanctum) dan daun kumis kucing (Orthosiphon stamineus) yang diekstrak dengan pelarut metanol menggunakan reagen kimia. Oleh karena itu, penelitian ini bertujuan untuk mengetahui jenis senyawa metabolit sekunder yang terkandung di dalam daun kemangi dan kumis kucing serta analisis aktivitas biologinya.

\section{METODE PENELITIAN}

Material

Daun kemangi (Ocimum sanctum) dan daun kumis kucing (Orthosiphon stamineus), metanol, pereaksi Mayer, pereaksi Wagner, pereaksi Danderdroff, $\mathrm{HCl} 2 \mathrm{~N}, \mathrm{FeCl}_{3}, \mathrm{~Pb}$ asetat, asam sulfat pekat, kloroform, kertas saring.

\section{Instrumentasi}

Timbangan analitik, blender, toples kaca, cawan porselen, beker glas, tabung reaksi, pipet tetes, batang pengaduk dan corong.

\section{Prosedur \\ Persiapan Sampel}

Tanaman kemangi (Ocimum sanctum) dan kumis kucing (Orthosiphon stamineus) diperoleh di daerah Juanda Surabaya. Masing-masing sampel dicuci dengan air untuk menghilangkan kotoran (debris) yang menempel. Setelah bersih, dipetik daunnya dan dikeringanginkan untuk mengurangi kadar air pada sampel. Sampel yang telah kering kemudian diblender supaya halus dan diayak hingga menjadi serbuk halus [10].

\section{Proses Ekstraksi}

Sebanyak 20 gram serbuk halus daun kemangi dimaserasi (direndam) ke dalam toples kaca yang berisi $600 \mathrm{~mL}$ pelarut metanol. Maserasi dilakukan selama 3 hari dan sesekali diaduk. Setelah 3 hari, disaring dengan kertas saring. Dilakukan 2 kali ulangan. Perlakuan yang sama juga dilakukan pada sampel daun kumis kucing [10].

\section{Proses Pengujian Fitokimia}

Metode skrining fitokimia dilakukan sesuai dengan penelitian yang dilakukan oleh [7].

\section{Uji Alkaloid}

a. Tes Dragendorff

Sebanyak $3 \mathrm{~mL}$ ekstrak uji ditambahkan 4 tetes reagen Dragendorff. Bila terbentuk endapan berwarna oranye kemerahan menunjukkan positif adanya alkaloid.

b. Tes Wagner

Sebanyak $3 \mathrm{~mL}$ ekstrak uji ditambahkan dengan 4 tetes reagen 
Wagner. Bila terbentuk endapan berwarna coklat kemerahan menunjukkan positif adanya alkaloid.

c. Tes Mayer

Sejumlah $3 \mathrm{~mL}$ ekstrak uji ditambahkan dengan 4 tetes reagen Mayer. Bila terbentuk endapan kuning keputihan menandakan adanya alkaloid.

\section{Uji Flavonoid}

Sebanyak $3 \mathrm{~mL}$ sampel ekstrak ditambahkan dengan $1 \mathrm{~mL}$ larutan $\mathrm{Pb}$ asetat. Positif adanya flavonoid bila terbentuk endapan berwarna kuning.

\section{Uji Saponin}

Sejumlah $3 \mathrm{~mL}$ sampel ekstrak dimasukkan ke dalam tabung reaksi, lalu ditambahkan dengan $5 \mathrm{~mL}$ air aquades, dipanaskan. Positif saponin bila terbentuk busa.

\section{Uji Tanin}

Sejumlah $3 \mathrm{~mL}$ sampel ekstrak dimasukkan ke dalam tabung reaksi lalu ditambah dengan 5 tetes larutan $\mathrm{FeCl}_{3}$. Positif menandakan adanya tannin bila terjadi perubahan warna biru tua atau hitam kehijauan.

\section{Uji Terpenoid dan Steroid}

Sebanyak $3 \mathrm{~mL}$ sampel ekstrak diuapkan dalam cawan porselen, lalu residu dimasukkan ke dalam tabung reaksi yang berisi kloroform $0,5 \mathrm{~mL}$, dilarutkan. Setelah itu, dimasukkan $0,5 \mathrm{~mL}$ asam asetat anhidrat dan $2 \mathrm{~mL}$ asam sulfat $\left(\mathrm{H}_{2} \mathrm{SO}_{4}\right)$ pekat melalui sisi tabung reaksi. Hasil positif menunjukkan terpenoid apabila terbentuk cincin kecoklatan, violet, merah atau jingga di antara batas larutan, dan positif steroid bila terbentuk cincin berwarna biru kehijauan.

\section{Uji Minyak Atsiri}

Sejumlah $3 \mathrm{~mL}$ sampel ekstrak diuapkan dalam cawan porselen. Hasil positif minyak atsiri bila timbul bau yang khas.

\section{HASIL DAN PEMBAHASAN}

Tujuan penelitian ini yaitu mengetahui kandungan senyawa fitokimia yang terdapat dalam ekstrak metanol daun kemangi dan daun kumis kucing. Sebelum skrining fitokimia, dilakukan proses ekstraksi dengan maserasi, yaitu proses merendam 20 gram sampel daun kemangi ke dalam toples kaca yang telah berisi pelarut metanol $600 \mathrm{~mL}$. Proses maserasi dilakukan selama 3 hari. Proses maserasi digunakan sebagai metode ekstraksi pada penelitian ini, agar zat-zat yang tidak tahan panas tidak akan rusak. Selain itu, pada maserasi akan terjadi proses plasmolisis yaitu pecahnya dinding sel tanaman akibat tekanan dalam dan luar sel sehingga senyawa-senyawa kimia pada tanaman akan lebih mudah ditarik oleh pelarut [11,12].

Metanol dipilih sebagai pelarut dalam penelitian ini karena metanol merupakan pelarut yang mampu melarutkan senyawa yang bersifat polar maupun non polar, seperti alkaloid, steroid, flavonoid dan saponin sehingga diharapkan dapat menarik lebih banyak senyawa kimia dalam tanaman [13].

Tabel 1. Hasil Skrining Fitokimia Ekstrak Metanol Daun Kemangi dan Daun Kumis Kucing

\begin{tabular}{|c|c|c|c|}
\hline \multirow{4}{*}{ No } & \multirow{4}{*}{ Skrining Fitokimia } & \multicolumn{2}{|c|}{ Hasil Pengamatan } \\
\hline & & Ekstrak & Ekstrak \\
\hline & & Metanol & Metanol \\
\hline & & Kemangi & Kumis \\
\hline 1 & Uji & - & - \\
\hline
\end{tabular}




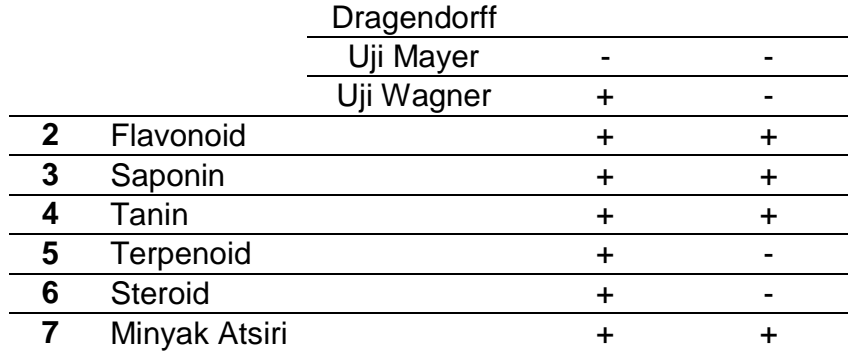

Hasil penelitian ini sesuai dengan yang dilakukan oleh [6], yang menyatakan bahwa kandungan senyawa fitokimia ekstrak metanol daun kemangi (Ocimum sanctum) mengandung flavonoid, terpenoid, steroid, dan saponin. Kandungan senyawa lain yang terdapat pada ekstrak metanol daun kemangi adalah alkaloid dan minyak atsiri.

Sementara itu untuk kandungan kimia ekstrak metanol daun kumis kucing (Orthosiphon stamineus) yaitu flavonoid, saponin, tannin dan minyak atsiri.

Fitokimia atau disebut dengan metabolit sekunder merupakan senyawa kimia yang dihasilkan oleh tanaman untuk berkomunikasi antar tanaman dan bentuk pertahanan dari serangan hama patogen, mikroba atau predator $[14,15]$ serta sebagai attractan (menarik serangga) [16,17]. Senyawa fitokimia ini dihasilkan secara alami pada tanaman dan terdapat di semua bagian tanaman, seperti akar, batang, daun, buah, bunga dan biji [18].

Senyawa-senyawa fitokimia/metabolit sekunder yang terkandung dalam daun kemangi dan daun kumis kucing antara lain alkaloid, tannin, flavonoid, saponin, terpenoid, steroid dan minyak atsiri. Keberadaan senyawa fitokimia tersebut kemudian dikaji secara teoritis aktivitas biologisnya.

Alkaloid adalah senyawa fitokimia yang paling banyak dijumpai pada semua bagian tumbuhan [10] dan memiliki cincin heterosiklik [19]. Alkaloid berfungsi sebagai zat antispasmodic (meredakan kejang otot yaitu menurunkan tegangan tinggi jaringan otot polos pada saluran pencernaan), antiinflamasi (pereda nyeri) dan sebagai antimikroba [20]. Senyawa alkaloid memiliki fungsi sebagai pelindung tanaman dari serangga dan herbivora (feeding deterrens) [21]. Aktivitas farmakologis alkaloid di antaranya anti-hipertensi, anti malaria, anti kanker dan analgesik [22].

Senyawa fenol memiliki aktivitas farmakologis yang luas dibandingkan dengan senyawa metabolit sekunder lainnya. Yang termasuk dari senyawa fenol antara lain tannin, flavonoid, glikosida dan sterol [23]. Flavonoid berfungsi sebagai antimikroba, sitoksisitas, anti-inflamasi dan anti alergi [24]. Kemangi dan kumis kucing merupakan tanaman obat, dan keduanya mengandung flavonoid. Hal tersebut sesuai dengan pernyataan [25] dan [26], di mana senyawa flavonoid pada tanaman obat memiliki aktivitas antioksidan yang tinggi. Antioksidan ini melindungi tubuh untuk melawan kanker dan penyakit degeneratif [27].

Tannin termasuk senyawa fenol yang berfungsi sebagai antioksidan untuk melawan radikal bebas, antiseptik dan hemostatik (menghentikan pendarahan) [28]. Aktivitas farmakologis lainnya yaitu sebagai astringent, antidiare dan antimikroba [29].

Senyawa saponin memiliki sifat sebagai anti-inflamasi [30], mampu mengikat kolesterol [20], melawan kanker dan meningkatkan imunitas tubuh [31]. Aktivitas biologi saponin yang lain yaitu mampu menghambat pertumbuhan bakteri dan jamur 
(antimikroba) dan sebagai benteng pertahanan tanaman yaitu mencegah tanaman dari serangan serangga [32]. Saponin mampu membunuh protozoa dan moluska dan juga sebagai antivirus [23].

Terpenoid merupakan senyawa fitokimia yang berfungsi sebagai phytooalexins, yang secara langsung dan tidak langsung berperan sebagai benteng pertahanan tanaman dari serangan hewan herbivora atau musuh alami lainnya [33]. karena memiliki rasa yang pahit sehingga merusak nafsu makan serangga (antifeedant) [34]. Namun, terpenoid juga memiliki aktivitas farmakologis yang penting yaitu antikanker, antimalaria dan antimikroba [23].

Steroid berperan penting dalam fisiologi dan biokimia makhluk hidup. Aktivitas farmakologis steroid antara lain merangsang pertumbuhan otot dan mengurangi massa lemak, obat kontrasepsi, antikanker, obat penenang, dan anti-inflamasi [35, 36].

Minyak atsiri digunakan sebagai bahan wewangian /parfum, produk make up, bahan pengawet dan aditif pada makanan ataupun sebagai obat alami, aromatherapy, antioksidan dan antimikroba [37].

Senyawa fitokimia yang dihasilkan oleh ekstrak metanol daun kemangi dan kumis kucing merupakan sumber potensial untuk menemukan obat baru, bahan tambahan pangan (pemanis, pengawet, pewarna), wewangian dan sebagai biopestisida nabati [38-40].

\section{KESIMPULAN}

Ekstrak metanol daun kemangi mengandung alkaloid, flavonoid, saponin, terpenoid, steroid dan minyak atsiri. Ekstrak metanol daun kumis kucing mengandung flavonoid, saponin, tannin dan minyak atsiri. Senyawa-senyawa fitokimia daun kemangi dan daun kumis kucing berpotensial sebagai bahan obat atau bahan lain yang bermanfaat yang dapat diaplikasikan tidak hanya untuk bidang farmasi saja namun juga di bidang ilmu yang lain.

\section{UCAPAN TERIMAKASIH}

Penulis menyampaikan terimakasih kepada Kementerian Ristekdikti yang telah mendanai penelitian ini melalui hibah Penelitian Dosen Pemula Tahun 2019.

\section{DAFTAR PUSTAKA}

[1] G. Asghari, M. Akbari, and M. AsadiSamani,"Phyochemical analysis of some plants from Lamiaceae family frequently used in folk medicine in Aligudarz region of Lorestan province," Marmara Pharmaceutical Journal., 21(3), 506-514, 2017.

[2] F. Naghibi, M. Mosaddegh, M.M. Mohammadi, A. Ghorbani,"Labiatae family in folk medicine in Iran: from ethnobotany to Pharmacology," Iran J Pharm Res., Volume 4, 63-79, 2010.

[3] H. Nasri, A. Baradaran, H. Shirzad, M. RafieianKopaei,"New concepts in nutraceuticals as alternative for pharmaceuticals," Int J. Prev Med., Volume 5, 1487-1499, 2014.

[4] I.M. Talaat, L.K. Balbaa, "Phisiological response of sweet basil plants (Ocimum basilicum L.) to putrescine and trans cinamic acid," American Eurasian Journal of Agricultural and Environmental Science, 8(4), 438-445, 2010.

[5] H.O. Edeoga, D.E. Okwu, B.O. Mbaebie, "Phytochemical Constituents of some Nigerian Medicinal Plants," African Journal of Biotechnology, Vol. 4, 685-688, 2005.

[6] A.A. Sangole, M.T. Sangole, "Phytochemical Screening of selected medicinal plants of the family Lamiaceae," International Journal of Life Science, Special Issue, 63-66, 2017.

[7] V. Rai, V.R. Pai, P. Kedilaya, S. Hegde, "Preliminary Phytochemical Screening of Members of Lamiaceae Family: Leucas linifolia, Coleus aromaticus and Pogestemon patchouli" Int. J. Pharm. Sci. Rev. Res., 21(1), 131-137, 2013.

[8] Z. Zakaria, R. Aziz, Y.L, Lachimanan, S. Sreenivasan and X. Rathinam, "Antioxidant activity of Coleus blumei, Orthosiphon stamineus, Ocimum basilicum and Mentha arvensis from Lamiaceae family," International Journal of Natural Engineering Science., 2(1), 93-95, 2008.

[9] A.F. Al-Rubaye, I.H. Hameed, M.J. Kadhim, "Review: Uses of Gas Chromatography-Mass 
Spectrometry (GC-MS) Technique for Analysis of Bioactive Natural Compounds of Some Plants," International Journal of Toxicological and Pharmacological Research., 9(1), 81-85, 2017.

[10] J.B. Harborne, Metode Fitokimia: Penuntun Cara Modern Menganalisis Tumbuhan. Terbitan Kedua. Bandung: ITB. 1998.

[11] D.R. Ningsih, Zusfahair, D. Kartika, "Identifikasi Senyawa Metabolit Sekunder Serta Uji Aktivitas Ekstrak Daun Sirsak Sebagai Antibakteri," Molekul., 11(1), 101-111, 2016.

[12] A. Redha, Nurdiansyah, "Efek Lama Maserasi Bubuk Kopra Terhadap Rendemen, Densitas, dan Bilangan Asam Biodiesel Yang Dihasilkan Dengan Metode Transesterifikasi In Situ," Jurnal Belian.,10(2), 218-224, 2013.

[13] E.B. Thompson, Drug Bioscreening, USA: Graceway Publishing Company, 1985.

[14] N.L. Paiva, "An introduction to the biosynthesis of chemicals used in plant-microbe communication," Journal of Plant Growth Regulation., Vol. 19, 131143, 2000.

[15] M. Iriti, F. Faoro, "Plant defense and human nutrition: phenylpropanoids on the menu," Current Topics in Nutrition Research.,Vol. 2, 47-65, 2004.

[16] B. Winkel-Shirley, "Biosynthesis of flavonoids and effects of stress," Current Opinion in Plant Biology., Vol 5, 218-223, 2002.

[17] L. Chalker-Scott, "Environmental significance of anthocyanins in plants stress response," Photochemistry and Photobiology ., vol. 70, 1-9, 1999

[18] M. Andjelkovic, J.V. Camp, B.D. Meulenaer, G. Depaemelaere, C. Socaciu, M. Verloo, "Ironchelation properties of phenolics acids bearing catechol and galloyl groups," Food Chem., Vol. 98, 23-31, 2006.

[19] E.B. Minarno, "Skrining Fitokimia Dan Kandungan Total Flavonoid Pada Buah Carica pubescens \& K. Koch Di Kawasan Bromo, Cangar, Dan Dataran Tinggi Dieng," El-Hayah., 3(2), 73-82, 2015.

[20] A.A. Nyarko, M.E. Addy, "Effects of aqueous extract of Adenia cissampeloides on blood pressure and serum analyte of hypertensive patients," Phytotherapy Res., 4(1), 25-28, 1990.

[21] R.J. Molyneux, R.J. Nash, N. Asano, Alkaloids: Chemical and Biological Perspectives, Vol. 11, Oxford: Pelletier SW, 1996.

[22] M. Wink, T. Schmeller, B. Latz-Briining, "Modes of action of allellochemical alkaloids: Interaction with neuroreceptors, DNA and other molecular targets," Journal of Chemical Ecology, Vol. 20, 1223-1280, 1998.

[23] M. Saxena, J. Saxena, R. Nema, D. Singh, A. Gupta, "Phytochemistry of Medicinal Plants," Journal of Pharmacognocy and Phytochemistry., 1(6), 168-182, 2013.

[24] A.R. Tapas, D.M. Sakarkar, R.B. Kakde, "Flavonoids as Neutraceuticals: A Review," Tropical Journal of Pharmaceutical Research., Vol. 7, 1089-1099, 2008.

[25] S. Sankhalkar, "Antioxidant enzyme activity, phenolics and flavonoid content in vegetative and reproductive parts of Moringa oleifera," Am J Pharmatechs Res, Vol. 4, 255-270, 2014.

[26] P. Siddhuraju, K. Becker, "Antioxidant properties of various solvent extracts of total phenolic constituents from three different agroclimatic origins of drumstick tree (Moringa oleifera Lam.) leaves," J Agric Food Chem, Vol. 51, 2144-2155, 2003.

[27] A. Jindal, P. Kumar, C. Jain, "Antifungal activity of flavonoids of Sida acuta Burm f. against Candida albicans," International Journal of Drug Development and Research, 4(3), 92-96, 2012.

[28] P. Dolara, C. Luceri, C. De Filipo, A.P. Femia, L. Giovannelli, G. Carderni, C. Cecchini, S. Silvi, C. Orpianesi, A. Cresci, "Red wine polyphenols influence carcinogenesis, intestinal microflora, oxidative damage and gene expression profiles of colonic mucosa in F344 rats," Mutation Research., Vol. 591, 237-246, 2005

[29] S.G. Killedar, H.N. More, "Estimation of tannins in different parts of Memecylon umbellatum Burm.," $J$ Phar Res, 3(3), 554-556, 2010.

[30] A.F. Vinha, M.O. Soares, "Phytochemicals characterization and radical scavenging activity of aqueous extracts of medicinal plants from Portugal," European Journal of Medicinal Plants., 2(4), 335-347, 2012.

[31] V.N. Daniel, I.E. Daniang, N.D. Nimyel, "Phytochemical analysis and mineral elements composition of Ocimum basilicum obtained in jos metropolis, plateau state, Nigeria" International Journal of Engineering \& Technology IJET-IJENS, Vol. 11, 161, 2011

[32] M.A. Lacaille-Dubois, H. Wagner, "Bioactive saponins from plants: An update. In Studies in Natural Products Chemistry," Elsevier Science, Vol. 21, 633-687, 2000

[33] D. McCaskill, R. Croteau, "Some caveats for bioengineering terpenoid metabolism in plants," Trends Biotechnology, Vol 16, 349-355, 1998

[34] J. Degenhardt, J. Gershenzon, I.T. Baldwin, A. Kessler, "Attracting friends to feast on foes: Engineering terpene emission to make crop plants more attractive to herbivore enemies," Current Opinion Biotechnology, Vol 14, 169-176, 2003.

[35] A. Sultan, A.R. Raza, "Steroids: A Diverse Class of Secondary Metabolites," Medicinal Chemistry, 5(7), 310-317, 2015

[36] N.P. Thao, B.T. Luven, E.J. Kim, J.I. Kang, H.K. Kang, "Steroidal constituents from the edible sea urchin Diadema saignyi Michelin induce apoptosis in human cancer cells," J Med Food, Vol. 18, 4553, 2015.

[37] A. Properzi, P. Angelini, G. Bertuzzi, R. Venanzoni, "Some biological activities of Essential Oils ," Medicinal and Aromatic Plants, 2(5). 1-4, 2013.

[38] G. Ramu, et al, "Preliminary Phytochemical And Antioxidant Study Of Hydroalcoholic Extracts From Selected Genera Of Indian Lamiaceae," Asian Pasific Journal of Tropical Biomedicinet, 2012.

[39] K.G. Ramawat, S. Dass, Herbal Drugs: Ethnomedicineto Modern Medicine. Heidelberg, Berlin: Springer-Verlag, 2009.

[40] D.E. Okwu, "Phytochemicals, vitamins and mineral contents of two Nigeria medicinal plants," Int. J. Mol. Med. Adv. Sci., 1(4), 375-381, 2005. 